\title{
Integrating Technology into Curriculum: Local Outcomes of a National Agenda
}

\author{
Chair: Bernard Cornu (FR) \\ Panel: David K. Stokes (US), Wanda Carrasquillo (US), Joyce Sibbett (US), \\ Jeanette Jones (US), Wolfgang Weber (DE), Anne McDougall (AU)
}

Keywords: integration, curriculum development, national policies, teacher education, collaborative leaming

The panel started with the presentation of a project by four colleagues from Westminster College (USA). This project was funded by the United States Department of Education within the pt3 programme: Preparing Tomorrow's Teachers to use Technology.

The U.S. Department of Education strongly wishes to overcome the digital divide and to have a population well versed in the use of computer based technology, and considers Teachers preparation as a major challenge in order to integrate information and communication technology into education. This is why the pt3 programme was launched in early 1999.

The School of education at Westminster College got an important funding in this project, and designed a strategy aimed at improving its preservice teachers' technology skills, attitude towards, and knowledge. For this, they radically revised their methods and core curriculum by integrating technology throughout.

The presentation showed the impact of this strategy at different level: impact on the school of education itself, its organisation, its methods and curriculum; impact on teacher trainers, and impact on the local schools and local teachers, with a particular emphasis on the role of school principals.

It increased team work, it helped changing the pedagogy and developing research. 
Concrete examples were presented, such as the use of videoconferencing, and the changes in the methodology course. It was clearly shown how trainers start with fear, but take the challenge and go to success!

Positive effects were stated, such as the better level of reflection of the students involved in the project, particularly in the 'eBoard' experience, and also the commitment to life-long learning as a driving force to get involved in learning about technology applications in the trainers teaching and personal life.

But there are also difficulties, such as the differences in teachers skills, the aspects of the time it requires for learning new skills, maintaining and applying them, and also the difficulty of assessing the students' use of multimedia resources.

The discussion then went to an international exchange, initiated by Wolfgang Weber and Anne McDougall, and then involving the audience.

A national policy helps local actors to develop and integrate computer technology in education. But even if equipment is progressing quickly, it needs changes in the pedagogy and in the teacher preparation. There are more and more schools well equipped, but only few use new media consequently under pedagogical aspects in most of the subjects to increase the quality of learning. Redesigning methods and curriculum in teacher training institution is a very good opportunity for progressing. But we need trainers and teachers ready to change, we need teachers who dare and pupils who dare!

Teachers need time, teachers need help, and the idea appeared of a 'curriculum navigator' in order to support teachers better. 